\title{
EFFECT OF PRE-POST TIG WELDING HEAT TREATMENT ON CAST NI SUPERALLOY
}

\author{
C. Saib1* ${ }^{*}$ M. Zaoui1, N. Menasri1, S. Amroune ${ }^{1}$, H. Ghouss ${ }^{2}$ \\ 1“Mohamed Boudiaf” University of M'sila, Faculty of Technology, Department of Mechanical Engineering, \\ LMMS, 28000 Algeria \\ 2“Badji Mokhtar" University of Annaba, Department of Mechanical Engineering, LMGMA, 23000 Algeria \\ *Corresponding author's e-mail address: cherif.saib@univ-msila.dz
}

\begin{abstract}
The effect of a pre (before) and post (after) heating welding treatment on the microstructure and mechanical properties of the scrap blades made of cast INC738LC superalloy is the main goal of the present investigation. The filler used in TIG welding was a INC 625 solution hardened superalloy as the proposed solution for hot cracking of the INC738LC cast superalloy in literature. The TIG welding was processed with respect to the constantly optimized parameters (current, voltage, speed, gas flux rate and number of passes) to make a mechanical properties comparison between the as received superalloy and the welded superalloy with heat treated specimens. The characterization techniques employed in this study are hardness measurements, tensile tests, optical microscopy and scanning electron microscopy. We found that the proposed preheating improves the TIG welding of the INC 738 LC superalloy specimens and the post welding heat treatment enhances its mechanical properties.
\end{abstract}

KEYWORDS: Ni-base superalloy, Microstructure, Heat treatment, Welding, Precipitation.

\section{INTRODUCTION}

Nickel-based superalloys are typically used in the combustor and turbine sections where elevated temperatures are maintained during operation [1]. Due to the poor machinability of Ni-superalloys, one of the important manufacturing approaches is vacuum investment casting [2]. Before being used in service, the as-cast components are often subjected to complex heat treatments designed to establish a controlled size and distribution of precipitates [1]. They must achieve the best combination of corrosion resistance and creep strength [3] as a result of their submission to a standard heat treatment [4].

The standard heat treatment of the INC 738 LC $\mathrm{Ni}$ superalloy consists of a solution heat treatment for 2 hours at $1120^{\circ} \mathrm{C}$ air cooling+ aging treatment at $845^{\circ} \mathrm{C}$ for $24 \mathrm{~h}$ air cooling, which will produce bimodal $\gamma^{\prime}(\mathrm{Ni3} \mathrm{Al})$ precipitates [5] consisting of primary cubical $\gamma^{\prime}$ precipitates and spherical secondary $\gamma^{\prime}$ precipitates. Their sizes are cited to be $40 \mathrm{~nm}$ to $70 \mathrm{~nm}$ for the fine precipitate, and $450 \mathrm{~nm}$ to $700 \mathrm{~nm}$ for the coarse precipitate[6]. The hardness of the cast INC $738 \mathrm{LC} \mathrm{Ni}$ superalloy rises to a maximum value $(\mathrm{Hv} \approx 485)$ at $827^{\circ} \mathrm{C}$ [7].

It is recognized that during long term severe service operation, blades made of INC738LC Ni superalloy undergo a series of time, temperature and stress dependent microstructural changes as porosity, micro shrinkages and other inhomogeneities in casting parts have been reported to limit their high temperature mechanical properties [8], such as creep strength and resistance to cracking [9].

Many researchers stated that the degradation is due to the formation of secondary phases [8], i.e.; the decomposition of $\gamma$, precipitates (loss in volume fraction) by the appearance of the $\beta$ phase [10], [11] or often overheating and subsequently corrosion [5]. Other researchers postulated that the failure is due to the decomposition of the carbides and borides which are the typical grain boundaries strengtheners [12].

The refurbishment of the pricey components of the gas turbine blades is preferred to replacing them, which is due to the high manufacturing cost of the hot parts of the damaged gas turbine blades used for power generation [13], especially those of first stage turbines made of the cast INC738LC Ni superalloy.

One of the economical industrial processed commonly used to repair the damaged blades of a gas turbine is the fusion welding TIG-Tungsten Inert Gas arc welding or GTAW [14]. TIG welding of the INC738LC Ni-superalloy blades without optimization of the welding parameters [15] can produce hot cracks or the grain-boundary liquation cracking due to the 
boron segregation [13]. Many studies report that the solution to the hot cracking mechanism during the welding of the Ni superalloy and the post-welding heat treatment is avoided by suitable and practical preheating $[16,8]$. It was also mentioned that a preheating at $1055^{\circ} \mathrm{C}$ can make the material ductile, with a hardness of about $340 \mathrm{H}_{\mathrm{V}}$, avoiding the formation of cracks after TIG welding [7], [8], while others propose the use of a hardened superalloy as INC 625 [17]. The thermal cycles during the welding of the Ni-base superalloy can decrease the mechanical properties of the welded joint [18]. Finally, after the TIG welding, the joined parts of the INC $738 \mathrm{LC} \mathrm{Ni}$ superalloy were subjected to post-welding heat treatment, its ultimate goal being to obtain a $\mathrm{Ni}$ superalloy with important mechanical properties [19] and to improve material service life [20].

The analysis of current literature shows that there is little research related to the mechanical properties of the cast Ni-base superalloy joints, using optimized parameters of TIG welding process and combined thermal regime (preheating and post-weld heat treatments).

\section{EXPERIMENTAL STUDY}

The Ni-base super-alloy used in this study was a INC738LC trade mark, with low carbon content. The sample was provided in an as-cast state, from the blade of a first stage gas turbine in the Electric Power Plant of M'sila, Algeria. The analysed blade had been in service for about $64,000 \mathrm{~h}$. Table 1 shows the nominal composition of the received base material.

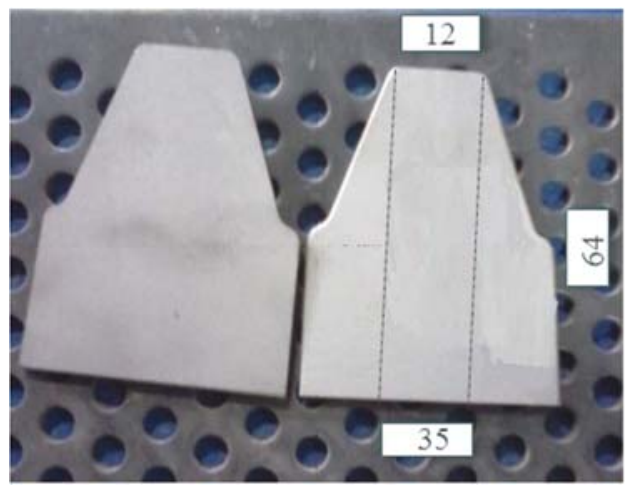

Fig. 1. The $2 \mathrm{~mm}$ thick plates cut from the blade root of the Ni superalloy INC738LC

Table 1. Nominal composition of the Ni based superalloy material used [15]

\begin{tabular}{|c|c|cc|}
\hline Element & Wt [\%] & Element & Wt [\%] \\
\hline $\mathrm{Al}$ & 3.65 & $\mathrm{Fe}$ & 0.23 \\
$\mathrm{Nb}$ & 0.86 & $\mathrm{Co}$ & 8.20 \\
$\mathrm{Mo}$ & 1.74 & $\mathrm{Ta}$ & 1.39 \\
$\mathrm{Ti}$ & 3.08 & $\mathrm{~W}$ & 2.95 \\
$\mathrm{Cr}$ & 15.40 & $\mathrm{Ni}$ & Bal. \\
\hline
\end{tabular}

The shape of the INC738LC superalloy plates is shown in figure 1 . The samples were cut from a gas turbine blade (MS9001-1st stage), using a wiredischarge cutting machine (EDM"AF 35", laboratory of the Maintenance of Industrial Equipment in the MIE company, Algeria) [21].

\subsection{Microhardness Measurement}

The microhardness of the as received INC738LC base material has been measured using a microhardness apparatus (LECO M-400-A hardness tester) and an indentation force value of $5 \mathrm{~N}$ for 15 seconds. The mean value of microhardness, obtained in 10 different measuring points, was $398.17 \mathrm{HV}$. The application of preheating is considered mandatory.

\subsection{Preheating}

Before welding the plates were subjected to the proposed preheating, as seen in figure 2 . It consists of a (re) solution treatment followed by primary precipitation treatment (at $1055^{\circ} \mathrm{C} / 4 \mathrm{hrs} / \mathrm{WQ}$ "water quench") which may lead to the regeneration of carbides and borides, providing some ductility to the superalloy. This preheating was inspired from the heat treatment applied by Danis \& al. [22] and Xu \& al. [8]. The proposed preheating cycle is an improvement in terms of time efficiency as compared to the time used for the preheating cycles of the U.M.T "University of Manitoba Heat treatment" by decreasing to $66.67 \%$, to $77 \%$ for the NUMT "New U.M.T" and to $62.5 \%$ for the FUMT "Furnace U.M.T" [23], thus saving the amount of the heat energy needed for preheating. Before the TIG welding process, plates were chamfered and a deep $\mathrm{V}$ groove of $35^{\circ}$ angle was machined.

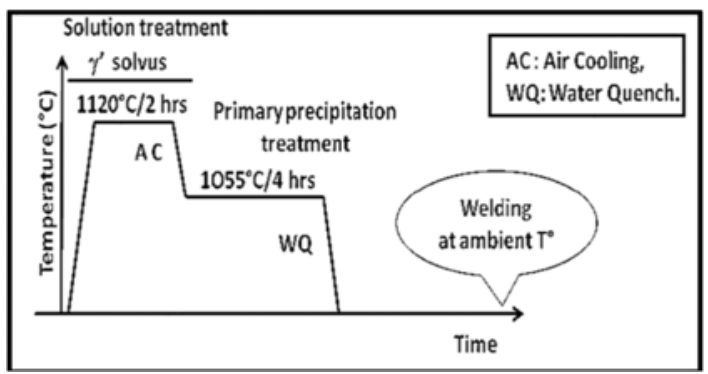

Fig. 2. The proposed diagram of preheating

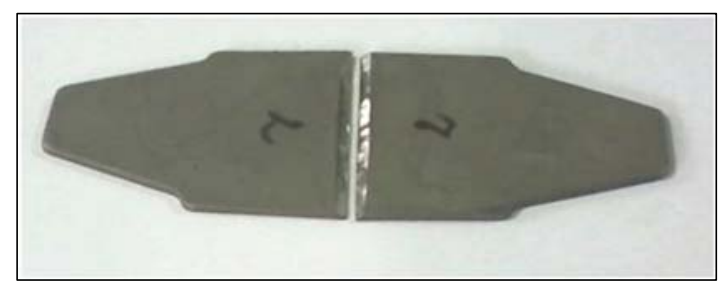

Fig. 3. Plates chamfered 


\subsection{Post-welding Heat Treatment}

After welding, post weld heat treatment (PWHT) is essential to improve the homogeneous microstructure and mechanical properties in the weld zone [20]. To do so, the welded parts were subsequently subjected to post-welding heat treatment as shown in figure 5, as defined by Wangyao \& al. [19].

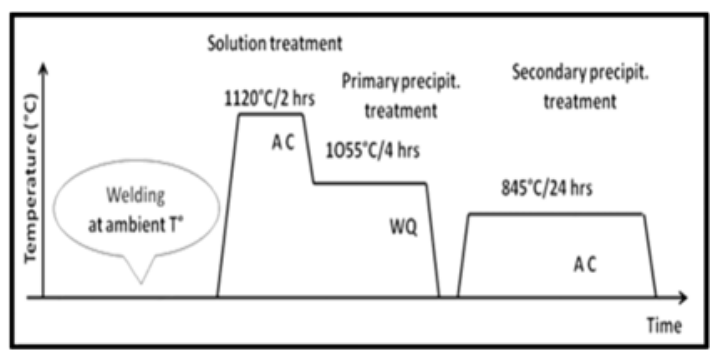

Fig. 5. The diagram of post-welding heat treatment

\subsection{Welding Process}

For the TIG welding process a Miller Syncrowave $350 \mathrm{~L}$ apparatus (XMT $450 \mathrm{CC} / \mathrm{CV}$ ) was used. The values of the optimized welding parameters (that were kept quite constant) are shown in table 2. Before welding, the joining surfaces were slightly treated with sandpaper P240 and cleaned with acetone. The welded joint obtained is shown in figure 4 .

Table 2. TIG welding parametrs

\begin{tabular}{|l|c|}
\hline \multicolumn{1}{|c|}{ TIG welding parameters } & $\begin{array}{c}\text { Millersyncrowave } \\
\mathbf{3 5 0} \text { L } \times(\mathbf{X M T} \\
\mathbf{4 5 0} \mathbf{C C} / \mathbf{C V})\end{array}$ \\
\hline Welding speed $[\mathrm{mm} / \mathrm{s}]$ & 0.4 \\
Argon gas rate flow $[1 / \mathrm{min}]$ & 8 \\
Number of passes & 2 \\
Welding current $[\mathrm{A}]$ & 40 \\
Welding voltage $[\mathrm{V}]$ & 10 \\
Filler used INC 625 $\varnothing[\mathrm{mm}]$ & 1.6 \\
Deep V groove angle $\left[{ }^{\circ}\right]$ & 35 \\
Space (distance) between Ni & 2 \\
superalloy plates[(mm] & 2 \\
\hline
\end{tabular}

INC625 filler was selected as suggested by Banerjee \& al. [17] and its chemical composition is shown in table 3.

Table 3. Chemical composition of the INC625 filler

\begin{tabular}{|c|c|c|c|}
\hline Element & Wt [\%] & Element & Wt [\%] \\
\hline $\mathrm{Al}$ & 0.40 & $\mathrm{Co}$ & 1.00 \\
$\mathrm{Nb}$ & 3.31 & $\mathrm{Ti}$ & 0.13 \\
$\mathrm{Mo}$ & 8.39 & $\mathrm{Ta}$ & 2.74 \\
$\mathrm{Cr}$ & 20.95 & $\mathrm{Ni}$ & Bal. \\
$\mathrm{Fe}$ & 0.27 & & \\
\hline
\end{tabular}

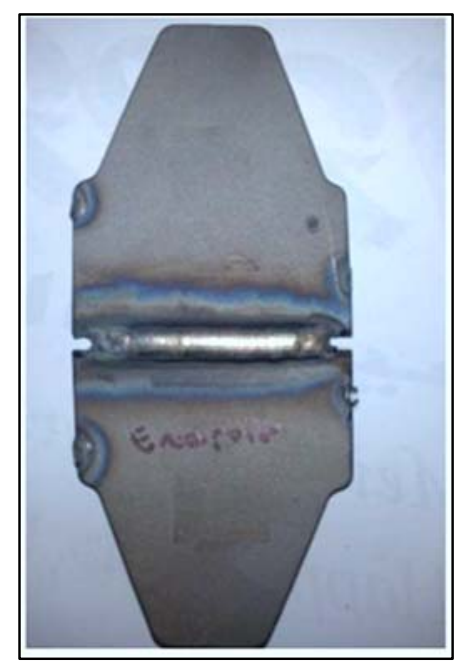

Fig. 4. The welded specimens

\subsection{Machining Tensile Test Specimens}

The tensile test specimens were cut from the welded plates after the post-welding heat treatment by use of the numerically controlled wire discharge machine (EDM"AF 35"). Figure 6 shows the shape and the measurements of the tensile experimental specimen. The welded zone is in the middle of the tensile-test specimens.

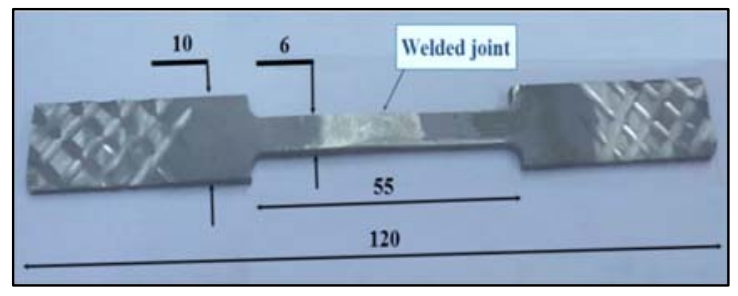

Fig. 6. The tensile test specimen

\subsection{Metallurgical and Mechanical Characterizations of Welds}

\subsubsection{Metallographic Characterization}

The metallographic observations of the base metal structure, welded and heat-treated parts were carried out by means of the computer-assisted "Leica Microsystems Belgium BVBA-DMLM" type microscope. The surface examination of the sample was possible by applying (Marble's reagent) for 30 seconds as dwell time. The average volume fraction or population of coarse $\gamma^{\prime}$ particles was determined by the surface area measurement by means of the "image J" software.

\subsubsection{Mechanical Characterizations}

The as received metal and the pre-post welding heat 
treated plates were subjected to the mechanical tests (microhardness measurements, tensile tests). The hardness of the pre-welding metal was taken in mean value (10 measurements). The hardness of the welded and post-welded heat-treated joints was quantified with a space of $0.5 \mathrm{~mm}$ from the base metal to the welded zones. The three specimens of INC738LC Ni superalloy as received and the three-welding heat treated specimens were also subjected to tensile tests by using a Zwick/Roell Z100 tensile experimental machine at a constant speed of $2 \mathrm{~mm} / \mathrm{min}$, as seen in Saib and Boumerzoug [15].

\subsubsection{Fracture Faces SEM Observations}

The cross-section observations of broken specimens after the tensile tests were performed by Scanning Electron Microscopy (SEM) TESCAN VEGA Easy Probe.

\section{RESULTS AND DISCUSSION}

\subsection{Microstructure Observations}

\subsubsection{Microstructure of the as-received Metal}

The as-received INC738LC superalloy was obtained from a blade, which had been operating in a gas turbine engine at high temperature for several years. Figure 7 shows the base metal microstructure. A dendritic structure is observed, which indicates that the blade was produced by a conventional casting process. It can be observed that the alloy has a multiphase microstructure composed of the FCC $\gamma$ austenitic matrix, bi-modal $\gamma$, Ni3(Ti, $\mathrm{Al})$ intermetallic precipitates (primary "coarse" and secondary "fine" ones), $\gamma-\gamma$ ' eutectic, carbides [20]. The coarse $\gamma^{\prime}$ precipitates had a $34 \%$ volume fraction.

\subsubsection{Microstructure of the Preheated Ni Superalloy}

\subsubsection{Microstructure of the Ni Superalloy after (re) Solution- Heat Treatment at $1120^{\circ} \mathrm{C}$ /2h/Air Cooling}

Figure 8 shows the $\gamma^{\prime}$ precipitates and the $\mathrm{M}_{23} \mathrm{C}_{6}$ carbides. The distinction from the (re) solution treatment (quenched) metal is that it contained a large fraction of fine $\gamma^{\prime}$ precipitates and spherical MC carbides (in grain boundary and intergranular) as compared to coarse $\gamma^{\prime}$ precipitates. The measured volume fraction of the coarse $\gamma^{\prime}$ precipitates decreased to $20 \%$.

\subsubsection{Microstructure of the INC738LC after the Primary Precipitation Heat Treatment $\left(1055^{\circ} \mathrm{C} / 4 \mathrm{~h} / \mathrm{WQ}\right)$}

Figure 9 shows the microstructure of the INC738LC $\mathrm{Ni}$ superalloy after isothermal heat treatment at $1055^{\circ} \mathrm{C}$, which is called primary precipitation.

The output of the volume fraction of the coarse $\gamma^{\prime}$ precipitates increased to $23 \%$. A segregation between the grains is observed, with the existence of a large fraction of blocky MC carbides (in grain boundary and intergranular). The shape of grain boundaries has a continuous and finer form which is the suitable shape to weld the superalloy without cracks, as mentioned by Thakur [7].

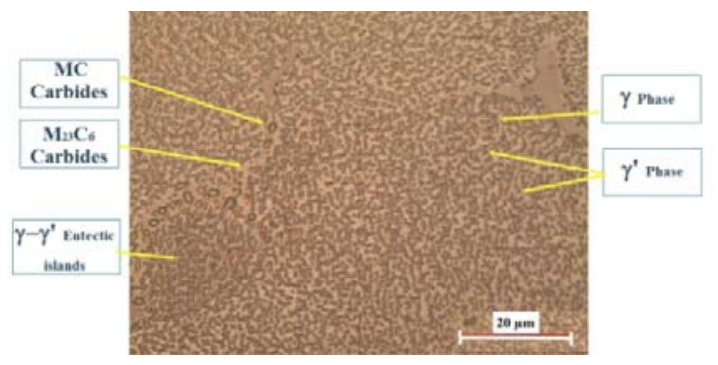

Fig. 7. Microstructure of the as-received metal

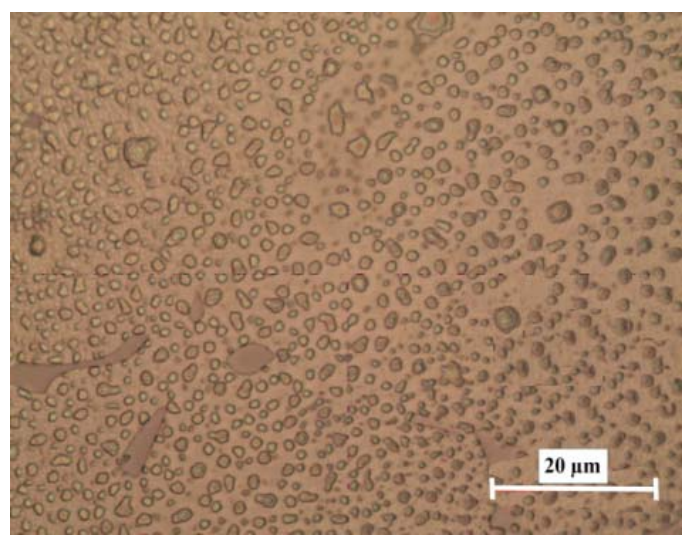

Fig. 8. Microstructure of the INC738LC superalloy after (re) solution- heat treatment at $1120^{\circ} \mathrm{C} / 2 \mathrm{~h} /$ air cooling

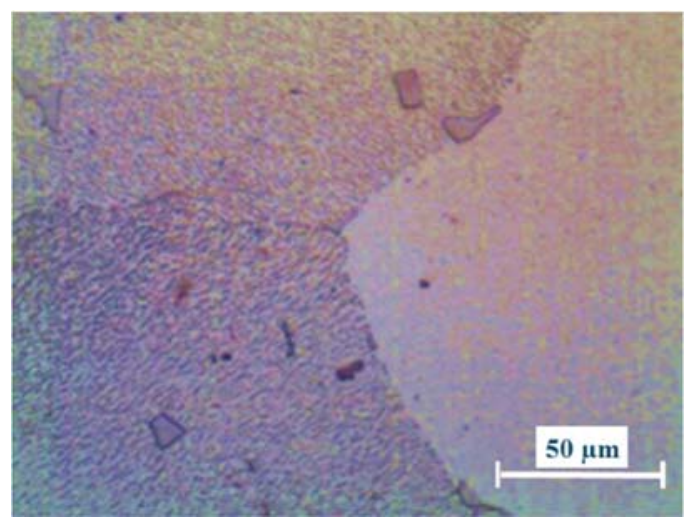

Fig. 9. Microstructure of the INC738LC Ni superalloy after primary precipitation heat treatment 


\subsubsection{Microstructure of the Welded $\mathrm{Ni}$ Superalloy}

Figure 10 shows the different zones of the INC738LC $\mathrm{Ni}$ superalloy microstructure welded joint. The welded joint microstructure differs significantly from the parent metal [24].

It can be observed a segregation in the microstructure of the base metal between the grains, one with fine $\gamma^{\prime}$ precipitates and another with bimodal $\gamma^{\prime}$ precipitates, with $24 \%$ as volume fraction of coarse $\gamma^{\prime}$ precipitates, in addition the presence of different carbides, borides; these constituents continued to exist in the HAZ at the base metal side. Laves phases are rejected to the interface between FZ and HAZ. In FZ, we detected the $\gamma^{\prime \prime}$ precipitation and the appearance of the $\delta$ phase, a small amount of the $\gamma^{\prime}$ precipitation, and Laves phase had the bulk appearance of the MC carbides.
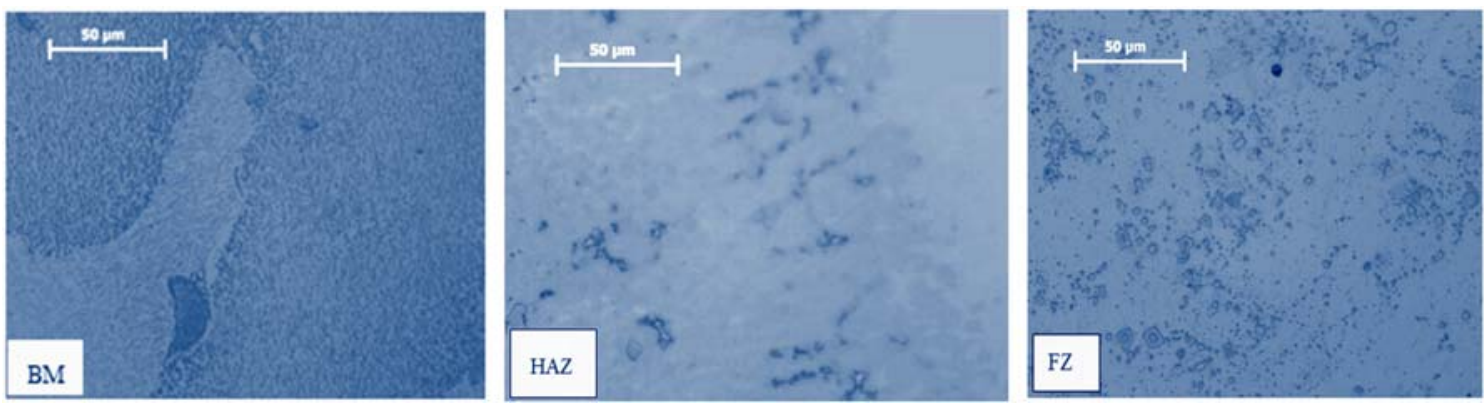

Fig. 10. Microstructures in the (BM, HAZ, FZ) of INC738LC Ni superalloy after welding

\subsubsection{Microstructure of the Post-welding Heat Treated Ni Superalloy}

Figure 11 shows the different zones of the welded joint microstructure after the post-welding heat treatment of the INC738LC Ni superalloy. We noticed the presence of the coarse $\gamma^{\prime}$ precipitates near the base metal, where their volume fraction was $44 \%$. On the FZ side, there are very fine $\gamma^{\prime}$ precipitates.
However, the difference in the $\gamma^{\prime}$ precipitates size between coarse and very fine is due to the formation of atoms of $\gamma^{\prime}$ precipitates, which could diffuse in more amount and/or more distance from the base metal zone to FZ after complete dissolution of all $\gamma^{\prime}$ precipitates during higher temperature of (re) solution treatment, and finally re-precipitate in uniform size after the aging heat treatment, as described by Wangyao \& al. [19].
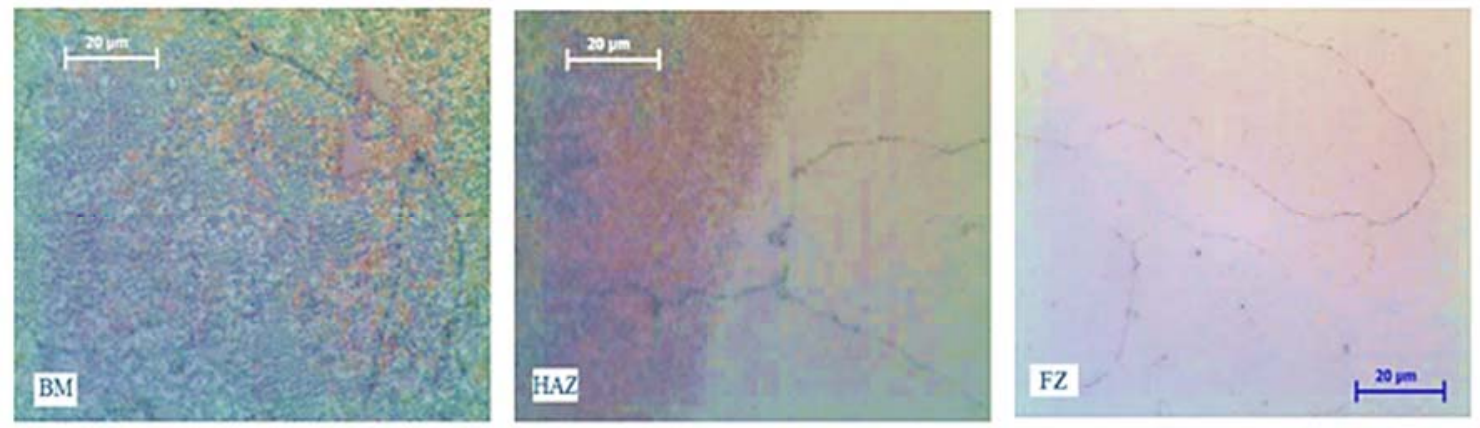

Fig. 11. The microstructures in the (BM, HAZ, FZ) of INC738LC Ni superalloy after post-welding heat treatment

\subsection{Mechanical Characterization of INC738LC Ni Superalloy}

\subsubsection{Microhardness Measurements}

\subsubsection{The as-received Cast INC738LC Ni Superalloy and the filler}

The mean microhardness value (10 measurements) of the base metal Ni superalloy INC 738 LC as received, was: $398.17 \mathrm{Hv}$. On the other hand, the mean microhardness of the INC625 filler metal was evaluated to have the value of $256.41 \mathrm{Hv}$.

\subsubsection{The Preheating of the INC738LC Ni Superalloy}

After the (re) solution heat treatment $\left(1120^{\circ} \mathrm{C} / 2 \mathrm{~h} / \mathrm{AC}\right)$, the average microhardness of the base metal became $418.59 \mathrm{Hv}$. However, the average microhardness of the Ni superalloy after the primary precipitation heat treatment ( 4 hours at $1055^{\circ} \mathrm{C} / \mathrm{WQ}$ ) reached the value of $351.44 \mathrm{Hv}$. 
The hardness of the metal decreases when the coarser $\gamma^{\prime}$ increases a little in volume fraction in comparison to the fine $\gamma^{\prime}$ precipitates.

\subsubsection{The welded INC 738 LC Ni Superalloy}

The values of the mean microhardness measured on the different zones of the welded joint are figured by the thick blue line in figure 12. After welding, high hardness values were obtained in the heat affected zone (HAZ), of about $500 \mathrm{Hv}$, while the hardness in the FZ was $370 \mathrm{Hv}$, and about $350 \mathrm{Hv}$ in the base metal.

\subsubsection{The Post-wlding Heat Treated INC 738 LC Ni Superalloy}

The values of the mean microhardness measured in the different zones of the welded bead after the different cycles of post-welding heat treatment are represented by the thin brown, thin green and thick red lines in figure 12. After welding followed by the (re) solution (quenching) and (re) precipitation treatment, the microhardness of the base metal was $450 \mathrm{Hv}$, whereas the HAZ approached $500 \mathrm{Hv}$, and the FZ was equal to $410 \mathrm{Hv}$. This minor raise in hardness was due to the (re)precipitation of the strengthening phases $\gamma^{\prime}, \gamma^{\prime \prime}, \delta$.

It was found that in the FZ, the precipitation of $\delta$, $\gamma^{\prime \prime}$ increased the yield strength. The high hardness values might also be due to the very dense or very fine $\gamma^{\prime}$ precipitates in the base metal and in HAZ, together with more $\gamma^{\prime}$ precipitates in the weld filler near the HAZ [25]. It was found that these $\gamma^{\prime}$ precipitates become coarser due to more dispersion by other elements such as aluminium and/or titanium from the base metal into FZ, followed by the formation of a coarser size of $\gamma^{\prime}$ precipitates in this area [26].

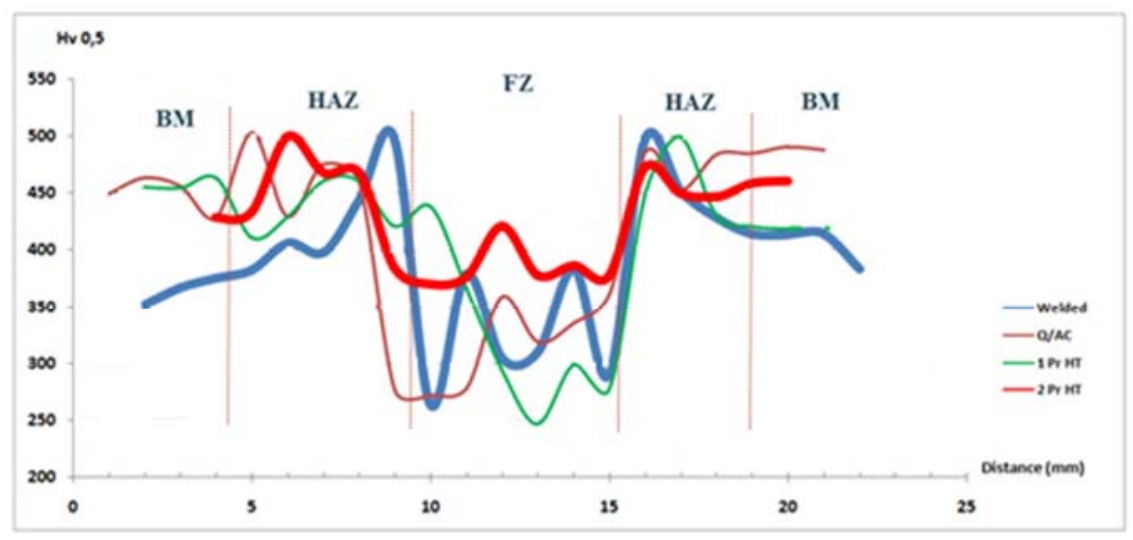

(Q/AC: quench air cooling, 1 Pr HT: $1^{n}$ precipitation heat treatment, $2^{\text {nd }} \operatorname{Pr} \mathrm{HT}: 2^{\text {ed }}$ precipitation heat treatment)

Fig. 12. Micro hardness measurements after welding and post-welding thermal cycles

\subsubsection{Tensile Experimental Study}

Tensile experiments were carried out at room temperature $20{ }^{\circ} \mathrm{C}$ on base metal (as received) specimens and on heat treated welded specimens (figure14), thus allowing to make a comparison of their mechanical characteristics. The tensile tests results are shown in figure 13 and table 4.

Figure 13 shows the tensile curves where we noticed that the tensile curves of the specimens consist of the following conventional zones: an elastic zone followed by a plastic zone, and finally the rupture. The higher mechanical strength (UTS) is realized in the base metal specimens followed by the heat treated post-welded specimens respectively. The ultimate tensile strength of the heat-treated welded specimens was similar to the as received metal (717.44 $\mathrm{MPa} \approx 721.21 \mathrm{MPa})$.

The ultimate tensile strength of the heat-treated welded specimens was higher by $\left(66.38 \mathrm{~N} / \mathrm{mm}^{2} \approx 70\right.$
$\mathrm{MPa}$ ) and the Young's modulus by $42 \mathrm{GPa}$ respectively, as compared to the welded specimens with the optimized TIG welding parameters that had not undergone any post heat treatment, as reported by Saib and Boumerzoug [15].

Table 4. UTS results

\begin{tabular}{|l|c|c|}
\hline Specimens & $\begin{array}{c}\text { UTS } \\
{[\mathbf{M P a}]}\end{array}$ & $\begin{array}{c}\text { E } \\
\text { [GPa] }\end{array}$ \\
\hline Cast reference [8] & 765 & 200 \\
BM (Base metal-as-received) & 721.21 & 191 \\
WOP (welded with optimized & 651.06 & 134 \\
parameters) [16] & 717.44 & 176 \\
HT (Welded Heat Treated) & \\
\hline
\end{tabular}

Figure 14 shows that the broken welded heattreated specimens after tensile tests were fractured in the FZ very close to the HAZ. 


\subsubsection{Fractography}

SEM observations were performed to analyse the nature of the fracture faces for the weld seams after the tensile experiments on the base metal (as received) specimens and the welding specimens with different thermal cycles, to relate the fracture characteristics to structure and properties. The fractured surfaces of the broken specimens of the base metal showed the cleavage fracture [27].

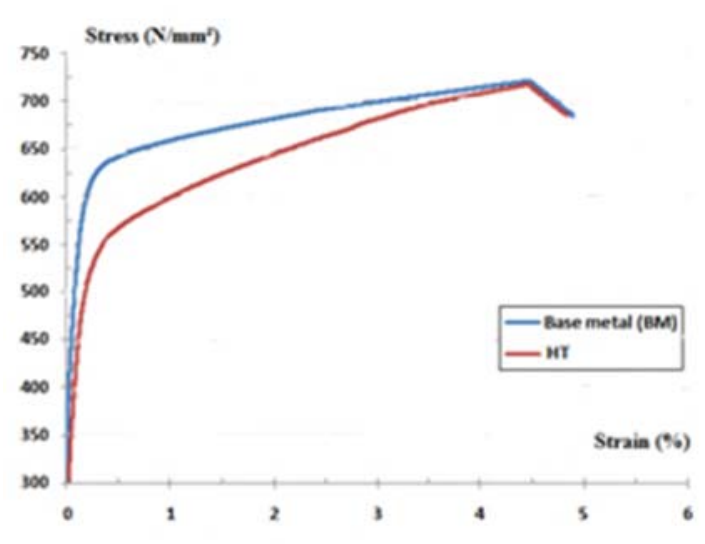

Fig. 13. Tensile curves of the post-welded heat-treated specimens (HT) versus the base metal (as-received)
In the fractured heat treated post-welded specimens shown in figure 15 , the structure consists of grain boundary voids produced during plastic deformation. The voids were coalesced, producing grain boundary cracks. The fine dimples present on the fracture surface indicate void coalescence and ductile intergranular fracture [28].

The white precipitates are primarily MC carbides distributed along the interdendretic regions and grain boundaries [27].

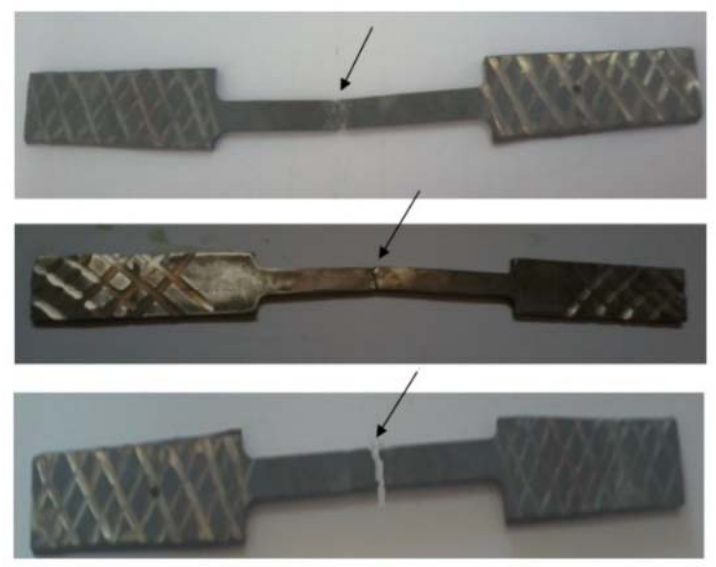

Fig. 14. The broken post-welding heat treated specimens after tensile test
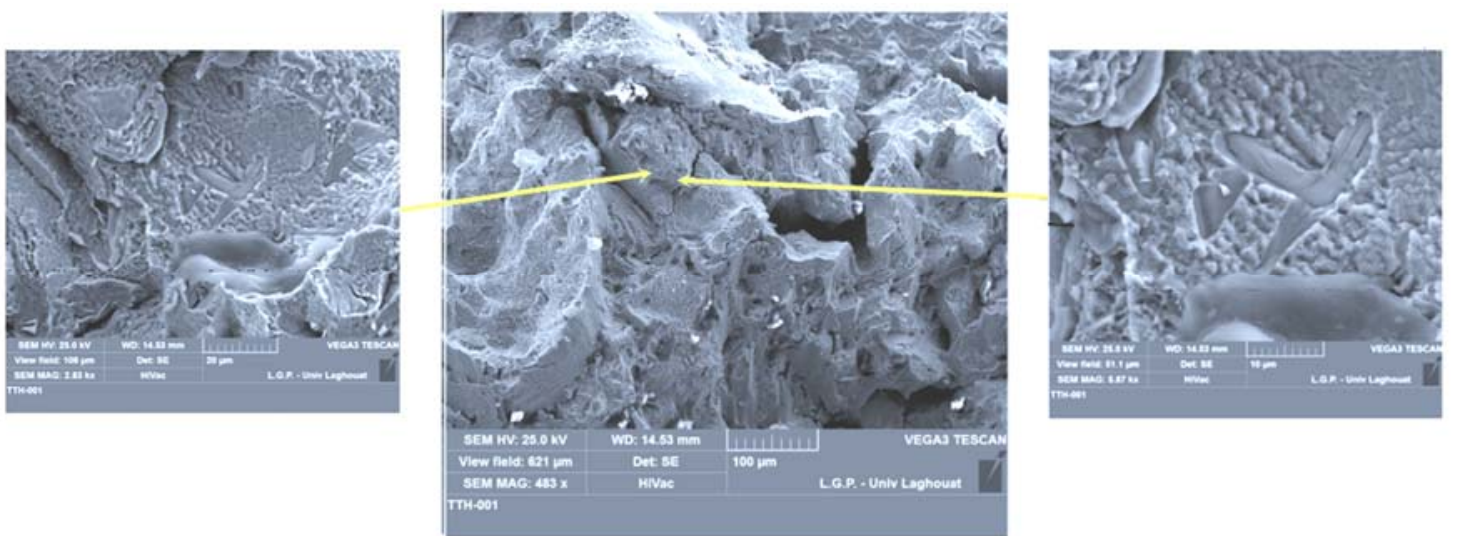

Fig. 15. SEM observations of a fracture faces of the specimen post-welding heat treated Ni superalloy

\section{CONCLUSIONS}

Through this investigation, the structural and mechanical properties of the welding of the INC 738LC superalloy with pre-post welding heat treatments were explored; the results can be briefly summarized as follows:

- The hardness of the as-received cast INC738 LC $\mathrm{Ni}$ superalloy was $398.17 \mathrm{Hv}$ and the coarse $\gamma$ ' precipitates volume fraction was about $34 \%$.

- The preheating of the cast INC 738 LC Ni superalloy allows its hardness to decrease to a low value of about 351.44; however the volume fraction was $23 \%$ as volume fraction of coarse $\gamma^{\prime}$ precipitates.

- During welding; when the cast Ni superalloy (base metal) is exposed to the high temperature of the TIG welding torch, in the HAZ at the base metal, the hardness of the welded $\mathrm{Ni}$ superalloy is allowed to change from $359.44 \mathrm{Hv}$ to $400 \mathrm{Hv}$, but the volume fraction of coarse $\gamma$ ' precipitates in the base metal was $24 \%$. In the FZ, the hardness was $410 \mathrm{Hv}$.

- The hardness of the post-welded heat-treated cast $\mathrm{Ni}$ superalloy (base metal) increases to reach the value of $450 \mathrm{Hv}, 44 \%$ being the volume fraction of coarse $\gamma^{\prime}$ precipitates. In the FZ, the hardness jumps to $410 \mathrm{Hv}$. 
- The ultimate tensile strength and Young's modulus of the heat-treated welded specimens were similar to those of the as-received metal.

- The welding of INC738 LC Ni superalloy free of cracks needs preheating and post heat treatments to improve the mechanical properties and life service of the blades, and this layout may be used to repair the scrap turbine blades.

\section{ACKNOWLEDGEMENTS}

We would like to thank the MEI Sonelgaz-M'sila, Pr. Z. Boumerzoug from the University of Biskra, Pr. N. Bouaouaja from the University of Setif, Pr. O. Allaoui from the University of Laghouat and Pr. F. Delaunois from the University of Mons-Belgique, for their support to our experiments.

\section{REFERENCES}

[1] Pollock T. M., Tin S., Nickel-Based Superalloys for Advanced Turbine Engines: Chemistry, Microstructure, and Properties, Journal of Propulsion and Power, vol. 22, no. 2, 2006, pp. 361-374. [2] Zheng X.G., Shi Y.-N., Lou L.H., Healing Process of Casting Pores in a Ni-based Superalloy by Hot Isostatic Pressing, Journal of Materials Science \& Technology 31 ,2015, pp. 1151-1157.

[3] Rakoczy L., Grudzień M., Tuz L., Pańcikiewicz K., Zielińska-Lipiec A., Microstructure and Properties of a Repair Weld in a Nickel Based Superalloy Gas Turbine Component, Advances in Materials Science, vol. 17, no. 2 (52), 2017, pp. 55-63 [4] El-Bagoury N., Waly M., Nofal A., Effect of various heat treatment conditions on microstructure of cast polycrystalline IN738LC alloy, Materials Science and Engineering: A487(1-2), 2008, pp. 152-161.

[5] Rani S., Agrawal A.K., Rastogi V., Failure analysis of a first stage IN738 gas turbine blade tip cracking in a thermal power plant, Journal of Case Studies in Engineering Failure Analysis 8, 2017, pp. 1-10.

[6] Balikci E., Mirshams R.A., Raman A., Microstructure evolution in polycrystalline IN738LC in the range 1120 to $1250^{\circ} \mathrm{C}$, Zeitschrift für Metallkunde, vol. 90 (2), 1999., pp.132-140.

[7] Thakur A., Microstructural responses of a nickel-base cast IN738 superalloy to a variety of pre-weld heat-treatments, Master thesis, University of Manitoba-Canada, 1997.

[8] Xu J., Lin X., Guo P., Hu Y., Wen X., Xue L., Liu J., Huang $\mathbf{W}$., The effect of preheating on microstructure and mechanical properties of laser solid forming IN-738LC alloy, Materials Science \& Engineering A 691,2017, pp. 71-80.

[9] Aghaie-Khafri M, Hajjavady M., The effect of thermal exposure on the properties of a Ni-base superalloy, Materials Science and Engineering: A 487(1-2), 2008. pp. 388-393.

[10] Zheng L., Xiao C., Zhang G., Brittle fracture of gas turbine blade caused by the formation of primary $\beta$-NiAl phase in Ni-base superalloy, Engineering Failure Analysis. 26, 2012, pp. 318-324.

[11] Jianting G., Ranucci D., Gherardi F., Precipitation of $\beta$ Phase in the $\gamma$ ' Particles of Nickel-Base Superalloy. Metallurgical Transactions A 15A, 1984, pp. 1331-1334.

[12] Foster M., Updegrove K., Welding superalloy articles,
Google Patents, 2001

[13] Fei P., Binggang Z., Houqin W., Ke H., Effect of pre-weld heat treatment on the microstructure and mechanical properties of electron beam welded IN738LC joint. Vacuum 168, 2019, pp. 108857, DOI: 10.1016/j.vacuum.2019.108857.

[14] Ola O. T., Ojo O. A., Chaturvedi M., Laser arc hybrid weld microstructure in nickel based IN738 superalloy, Materials Science and Technology, 2013, 29(4), pp. 426-438.

[15] Saib Ch., Boumerzoug Z., Effect of welding current on microstructures and mechanical properties of welded Ni-base superalloy INC738LC, World Journal of Engineering. 15(1), 2018, pp. 14-20.

[16] Ola O. T., Ojo O.A., Chaturvedi M., Birur A., Pre-weld heat treatment of $\gamma^{\prime}$ precipitation strengthened nickel-based superalloys, patent No. WO2015010200A1, 2015.

[17] Banerjee K., Richards N., Chaturvedi M., Effect of filler alloys on heat-affected zone cracking in preweld heat-treated IN738 LC gas-tungsten-arc weld". Metallurgical and Materials Transactions A, 36(7), 2005, pp. 1881-1890.

[18] Makri H., Investigation on microstructure and mechanical properties of E36-3 steel welded joint, The annals of "Dunarea de Jos" University of Galati, fascicle XII, Welding Equipment and Technology, no. 27, 2019, ISSN 1221- 4639, pp. 47-54

[19] Wangyao P., Homkrajai W., Asavavisithchai S., Effect of post weld heat treatments on TIG-welded microstructures of superalloy IN-738. Chiang Mai J Sci, 36, 2009, pp. 320-330.

[20] Mithun K., Saraswathamma K., Verma D. K., Effect of post weld heat treatment soaking time on microstructure and mechanical properties of TIG welded grade 91 steel, Journal of Metals, Materials and Minerals, 29(2), 2019, pp. 42-50, DOI:10.14456/jmmm.2019.17.

[21] Boumerzoug Z., Saib C., Thermal Cycle Simulation of Welding Process in INC 73 LC Superalloy, Key Engineering Materials 735, 2017, p.75-79. DOI: org/10.4028/ www.scientific.net /KEM.735.75

[22] Danis Y., Avieu C., Lacoste E., Larrouy Th., Quenisset J.M., An investigation on thermal, metallurgical and mechanical states in weld cracking of Inconel 738LC superalloy. Materials \& design, 31(1), 2010, pp. 402-416.

[23] Ola O.T., Oj O.A., Chaturvedi M.C., On the development of a new pre-weld termal treatment procedure for preventing heataffected zone (HAZ) liquation cracking in nickel-base IN 738 superalloy, Philosophical Magazine 94(29), 2014, pp. 3295-3316.

[24] Hamza S., Boumerzoug Z., Helbert A. L., Bresset F., Baudin T., Texture analysis of welded $304 \mathrm{~L}$ pipeline steel, Journal of Metals, Materials and Minerals, 29(3), 2019, pp. 32-41, DOI: 10.14456/jmmm.2019.31.

[25] Royer F., Fonctionnement et singularités du procédé de fusion laser sélective : Ilustration par application à deux superalliages à base nickel et considérations énergétiques, doctoral thesis, ENMP Paris-France, 2014.

[26] Osoba L., uda M., Tracking heat-affected zone cracking susceptibility in standard and modified heat treated IN 738 superalloy welds, High Performance and Optimum Design of Structures and Materials, 137, 2014, pp. 37.

[27] Han K., Wa H., Peng F., Zhang B., Shen L., Investigation of microstructure nd mechanical performance in IN738LC joint by vacuum electron beam welding. Vacuum, 162, 2019, pp. 214-227.

[28] Kumar A. L, Chaitanya N. B., Kumar B. S., Nath V. S., Singh P. K., Study of Tensile Fracture Mechanisms of a Ni-base Superalloy Super cast 247A, Procedia materials science, 2014 (5), pp. 1090-1096. 